\title{
Changes in the strength of the Nordic Sea Overflows over the past 3000 years
}

Paola Moffa-Sanchez ${ }^{1,2^{*}}$, Ian R. Hall ${ }^{1}$, David J. R. Thornalley ${ }^{3,4}$, Stephen Barker ${ }^{1}$, Connor Stewart ${ }^{1}$

\footnotetext{
${ }^{1}$ School of Earth and Ocean Sciences, Cardiff University, CF10 3AT, UK.

${ }^{2}$ Now at Department of Marine and Coastal Sciences, Rutgers University, New Brunswick, NJ, 08904, US. ${ }^{3}$ Department of Geography, University College London, Pearson Building, Gower Street, London, WC1E 6BT, UK.

${ }^{4}$ Department of Geology and Geophysics, Woods Hole Oceanographic Institution, Woods Hole, MA 02543, USA.

*Corresponding author. E-mail: paolamoffa@marine.rutgers.edu
}

The Nordic Overflows constitute the densest component of the deep limb of the Atlantic Meridional Overturning Circulation (AMOC). Changes in the vigour of the overflows may have had important climatic effects in the past and may also have in the future. Yet, evidence for multidecadal to millennial changes in the deep limb of the AMOC and their potential relationship to North Atlantic climate variability during the Holocene remains weakly constrained. Here we present grain size data, as a proxy for nearbottom current speed, from sub-decadal to decadally resolved sediment cores located in the direct pathway of the two Nordic Overflows east and west of Iceland, the Iceland Scotland Overflow Water (ISOW) and the Denmark Strait Overflow Water (DSOW), respectively. The results show no clear relationship between reconstructed changes in the vigour of the Nordic Overflows and the well-known periods of centennial-scale climate variability recorded in the North Atlantic region. However, well-defined millennial-scale trends are found in both of the overflow strength records over the last 3000 years, which were possibly related to hydrographic reorganizations in the Nordic Seas, driven by the decrease in Northern Hemisphere summer insolation changes over the Neoglacial period. A comparison between the near-bottom flow speed reconstructions from ISOW and DSOW suggest an anti-phased relationship between the Nordic Sea Overflows east and west of Iceland over the last 3000 years. This feature has been observed in climate models potentially as a result of shifts in the deep water formation sites as a response to changes in atmospheric patterns over the Nordic Seas. 


\section{Introduction}

41 The warm salty surface waters, originating in the tropics, are transported to the higher latitudes across the North Atlantic reaching the Nordic Seas and Arctic Ocean. During their northward transit these inflowing Atlantic waters lose heat to the atmosphere, via air-sea exchange, increase their density and eventually sink to form intermediate and deep water masses, via convective processes, in the Nordic Seas. This process is often referred as the Atlantic Meridional Overturning Circulation (AMOC) and since it regulates the transport and distribution of heat, nutrients and $\mathrm{CO}_{2}$ around the Earth's oceans, changes in the strength and structure of it have often been thought to be involved in past climate variability, particularly in the North Atlantic region [e.g. Kuhlbrodt et al., 2007].

The submarine ridge that lies between Greenland and Scotland, the Greenland-Scotland Ridge (GSR), forms a physical barrier that controls the exchange of deep dense waters between the Nordic Seas and the North Atlantic [e.g. Meincke, 1983] (Figure 1). The dense waters that flow across the GSR into the North Atlantic Basin are collectively referred to as the Nordic Seas Overflows. These overflows are of pivotal importance to the climate system since they provide $\sim 30 \%$ of the volume transport of the lower limb of the AMOC and downslope entrainment with intermediate waters when entering the Atlantic Basin, increases the volume transport of the deep waters by three fold [Dickson and Brown, 1994; Hansen et al., 2004]. Furthermore, the overflow of deep waters into the North Atlantic also helps set the pressure gradient at the surface, which contributes significantly to the northward inflow of warm waters into the Nordic Seas [Hansen et al., 2010]. The advection of heat and salt to the high latitudes via the Atlantic inflow is important not only for ameliorating the climate in Western Europe [Rossby, 1996] but also for promoting deep water formation. Additionally, modelling studies have suggested that the density of the overflows and their transport can 
65 also influence the surface hydrography south of the GSR, namely the subpolar gyre circulation [Born et al., 2009; Zhang et al., 2011].

67

Future climate simulations under increasing atmospheric $\mathrm{CO}_{2}$ levels predict a change in the freshwater budget in the Arctic Ocean and Nordic Seas as a result of a decline in Arctic sea ice cover, melting of the Greenland Ice Sheet and increase in circum-Arctic river run-off [Stocker et al., 2013]. The addition of freshwater into the high latitudes may lower the surface ocean salinity and reduce the formation of dense waters in the Nordic Seas, which would potentially weaken the overflow transport across the ridge, possibly affecting the AMOC [Hansen et al., 2004; Wilkenskjeld and Quadfasel, 2005; Rahmstorf et al., 2015].

However, prior to reaching any conclusion on the anthropogenic drivers of climate change and their potential effect on the freshening and weakening of the overflows and the AMOC, it is necessary to extend the instrumental records of overflow vigour back in time to improve our understanding of the natural variability of these key components of the AMOC. On centennial time-scales, proxy reconstructions have revealed abrupt changes in the strength and/or depth of the overflow boundary currents at times corresponding to well-known millennial-centennial scale climatic oscillations, such as the $8.2 \mathrm{kyr}$ event [Ellison et al., 2006], the $2.7 \mathrm{kyr}$ event [Hall et al., 2004] and the Little Ice Age [Bianchi and McCave, 1999], and over the Holocene [Thornalley et al., 2013]. This ocean-climate link suggests that the Nordic Sea Overflows, and their role in setting the strength of the AMOC, play a leading role in modulating climate variability over the current interglacial.

Here we present near-bottom flow speed reconstructions from two sub-decadal to decadally resolved marine sediment cores which are strategically located within the present day flow 
90 path of the two main Nordic Sea Overflows, namely Iceland Scotland Overflow Water

91 (ISOW) and Denmark Strait Overlow Water (DSOW) respectively, and which span the last 3000-4000 years. In order to reconstruct the relative flow speed changes we use the

93

94 paleocurrent proxy 'sortable silt' mean grain size $(\overline{\mathrm{SS}})$, which is the average of the $10-63 \mu \mathrm{m}$ terrigenous fraction [McCave et al., 1995]. Size sorting in this size range responds to hydrodynamic processes and can therefore be used to infer relative changes in the speed of the depositing current [McCave et al., 1995; McCave and Hall, 2006].

\section{Hydrographic Setting: The Nordic Overflows}

Deep water formation in the Nordic Seas sets a horizontal density gradient across the GSR which drives the transfer of these dense waters over the sill as the Nordic Sea Overflows [Hansen et al., 2001]. The rate of dense water export by the overflows into the North Atlantic Basin is hydraulically controlled and is proportional to the cross-sill density difference of the water masses and to the upstream reservoir height [Whitehead, 1998]. Alteration of these factors drives changes in the vigour of the overflows reaching the Atlantic Basin.

The densest overflow waters pass through the deepest passages of the GSR, the Denmark Strait and the Faroe Bank Channel. As such, the Nordic Sea Overflows are divided into two major branches east and west of Iceland: the Iceland Scotland Overflow Water (ISOW) and the Denmark Strait Overflow Water (DSOW), respectively (Figure 1). While the two overflows are different primarily because of the differing sill geometries and the physical properties of their upstream source waters, both overflows contribute $\sim 3 \mathrm{~Sv}$ each $\left(1 \mathrm{~Sv}=10^{6}\right.$ $\mathrm{m}^{3} \mathrm{~s}^{-1}$ ) to the total volume flux of dense waters ventilating the deep subpolar North Atlantic [Olsen et al., 2008 and references therein]. Once the overflows cross the GSR, they descend over the sill subsequently entraining intermediate waters found in the Irminger and Iceland 
115 Basins, such as Labrador Sea Water and other Subpolar Mode Waters. Thereafter, the

116 overflows continue as density-driven bottom currents, following the bathymetry whilst

117 undergoing further mixing with the overlying waters. This intensive downstream entrainment

118 and mixing increase the initial volume transport by three-fold and significantly alter the

119 hydrographic properties of the overflow waters [Price and Baringer, 1994]. The two

120 overflows (ISOW and DSOW) merge south of the Denmark Strait forming the upper and

121 lower branches of the Deep Western Boundary Current (DWBC) on reaching Cape Farewell,

122 although here the different water masses are still distinguishable based on potential density

123 [Holliday et al., 2009]. The DWBC subsequently flows around the Labrador Basin (Figure 1)

124 and in combination with Labrador Sea Water (LSW) eventually forms North Atlantic Deep

125 Water (NADW), which constitutes the deep limb of the AMOC.

126

127 3. Materials

$128 \quad 3.1 . \quad$ Core settings

129

130 Sediment core RAPiD-17-5P (61 $28.90^{\prime} \mathrm{N}, 19^{\circ} 32.16^{\prime} \mathrm{W}, 2303 \mathrm{~m}$ water depth) is situated on

131 the deeper section of the south Iceland insular rise that runs along the northern edge of the

132 South Iceland Basin (Figure 1) [Thornalley et al., 2010]. Numerous hydrographic and hydro-

133 chemical studies focusing on the deep circulation in the Iceland Basin [Van Aken, 1995; van

134 Aken and Becker, 1996; Bianchi and McCave, 2000; Fogelqvist et al., 2003] and the

135 Conductivity Temperature Depth (CTD) data obtained during the CD159 cruise [McCave,

$1362004]$ show bottom temperatures and salinities of $\sim 2.8-3^{\circ} \mathrm{C}$ and $\sim 34.97$ respectively at the

137 core site, which confirm that RAPiD-17-5P lies directly in the present day pathway of the 138 ISOW. 
140 Sediment core RAPiD-35-COM is a composite record comprising box-core RAPiD-35-25B

141 [Moffa-Sanchez et al., 2014b] and the piston core RAPiD-35-14P $\left(57^{\circ} 30.25^{\prime} \mathrm{N}, 48^{\circ}\right.$

14243.34 'W, $3484 \mathrm{~m}$ water depth) both recovered from the same site located on the Eirik Ridge,

143 south east of the southern tip of Greenland. CTD transects on the Eirik Ridge, show a

144 temperature of $<2^{\circ} \mathrm{C}$ and salinity of 34.9 at the core location (3500 $\mathrm{m}$ water depth) [Holliday

145 et al., 2009]. CTD measurements obtained during the CD159 cruise at two neighboring 146 locations $\left(58^{\circ} 14 \mathrm{~N}, 47^{\circ} 00 \mathrm{~W}\right.$ and $\left.56^{\circ} 45 \mathrm{~N}, 52^{\circ} 27 \mathrm{~W}\right)$ in the Labrador Basin show 147 temperatures and salinities of $1.6-1.75^{\circ} \mathrm{C}$ and $34.86-34.89$ respectively ( $>3000$ water depth) 148 [McCave, 2004]. Both lines of evidence indicate that the core location currently lies in the 149 pathway of the DSOW (defined as $>27.88 \mathrm{~kg} / \mathrm{m}^{3}$ ) (Hunter et al., 2007a).

\subsection{Core-chronology}

152 The core-chronology for RAPiD-17-5P has been previously published in Moffa-Sánchez et 153 al. [2014a] and it is presented in the Supplementary Material of this article. The age model

154 for RAPiD-17-5P was constructed based on a linear fit through the twelve radiocarbon dates,

155 implying a constant sedimentation rate of approximately $80 \mathrm{~cm} / \mathrm{kyr}$ for the last 9000 years $156\left(\mathrm{R}^{2}=0.99\right)$ [Moffa-Sanchez et al., 2014a]. The good linear fit to the calibrated dates suggests a probable lack of abrupt changes in the rate of the sediment deposition during the time interval studied. The core was sampled at $0.5 \mathrm{~cm}$ intervals and thus each data point represents an

159 integrated time of $\sim 6$ years. The core-top of RAPiD-17-5P was lost as the piston core over 160 penetrated [McCave, 2004]; the top $1 \mathrm{~cm}$ has a calibrated age of $\sim 1737$ years AD.

162 The age-model for RAPiD-35-14P $\left(5^{\circ} 30.25^{\prime}, 48^{\circ} 43.34^{\prime}, 3484 \mathrm{~m}\right)$ was constructed using ten

$163{ }^{14} \mathrm{C}$ AMS dates measured from monospecific samples of the planktonic foraminifer 164 Neogloboquadrina pachyderma (sinistral) $(>150 \mu \mathrm{m})$ and were converted to calendar years 
using MarineCal13 dataset [Reimer et al., 2013]. The core-chronology was constructed using

166 a Bayesian Age-Model software; BChron [Haslett and Parnell, 2008; Parnell et al., 2011]

167 (Table 1, Figure 2). Based on the ${ }^{14} \mathrm{C}$ dating and further validated by the coarse fraction

168 percent in the two cores, the splicing point between the bottom of the box-core RAPiD-35-

169 25B [Moffa-Sanchez et al., 2014b] and the piston core RAPiD-35-14P, was assigned to a

170 depth of $30 \mathrm{~cm}$ in RAPiD-35-14P (Figure 2). This spliced record is referred to as RAPiD-35-

171 COM hereinafter.

172

173 4. Methodology

\section{$174 \quad$ 4.1. Sortable Silt}

175 Sortable silt mean grain size $(\overline{\mathrm{SS}})$ is defined as the mean grain size of the $10-63 \mu \mathrm{m}$ 176 terrigenous material [McCave et al., 1995]. The particles in this size range behave non177 cohesively (i.e. without adhering to one another) and are therefore sorted by primary particle

178 size in response to hydrodynamic processes. Consequently, $\overline{\text { SS }}$ can be used to infer relative 179 changes in the near-bottom speeds of its depositing current [McCave et al., 1995; McCave and Hall, 2006].

182 The sediment for $\overline{\mathrm{SS}}$ analysis was prepared following the method outlined by McCave et al.

183 [1995]. This involves the removal of carbonate and biogenic opal using $2 \mathrm{M}$ acetic acid and $2 \mathrm{M}$ sodium carbonate at $85{ }^{\circ} \mathrm{C}$ for 5 hours. The acid step was repeated twice (each batch of acid was left in the samples for at least 24 hours) it was followed by a water rinse before the addition of sodium carbonate to the sample. The samples in sodium carbonate were then

187 placed in the water bath for 5 hours at $85{ }^{\circ} \mathrm{C}$ and vigourous stirring was carried out 3 times 188 during this time interval to promote dissolution of the biogenic silica. Once the carbonate and biogenic opal removal steps were completed the samples were suspended in $0.2 \%$ 
sodium hexametaphosphate (Calgon) dispersant in $60 \mathrm{ml}$ Nalgene bottles. To ensure full

191 disaggregation, all samples were placed on a rotating wheel for a minimum of 24 hours and were finally ultrasonicated for 3 minutes immediately prior to the sample analysis using a Beckman Multisizer 3 Coulter Counter. For each run, two aliquots of the same sample (150 $\mu 1)$ were pipetted into the beaker as a measure to minimise the procedural error attached to pipetting.

As detailed in Bianchi et al. [1999], the Coulter Counter aperture size was set for $140 \mu \mathrm{m}$. A particle sizing and counting threshold was set to $8 \mu \mathrm{m}$ and $10 \mu \mathrm{m}$ respectively, with a sizing

199 bin of 256 and the total count of 70,000 particles in the $10-63 \mu \mathrm{m}$ size range was performed

200 for each run. The samples were run with a suspended particle concentration of $<4 \%$ 201 (generally between 1-2.5\%). Initial analysis showed poor precision (up to $3 \mu \mathrm{m}$ ), which was caused by the settling of the particles from the sample in suspension over the period of the analyses. This was overcome by elevating the speed of the stirrer (speed 54). Additionally, the volume of electrolyte (Isoton ${ }^{\mathrm{TM}}$ ) used to suspend the sample was increased in order to avoid turbulence and drawdown of bubbles into the sample at the higher stirrer speed. The sample blank under the higher stirrer speed did not produce significant background noise.

207 Each sample was run a minimum of twice in an arbitrary order and over several days. The average standard deviation from the duplicate or triplicate runs was \pm 0.6 and $\pm 0.1 \mu \mathrm{m}$ in RAPiD-17-5P and RAPiD-35-COM, respectively.

\section{$210 \quad$ 4.2. Statistical and Spectral Analysis}

211 Single Spectral analysis was performed using a multi-taper method [Pardoiguzquiza et al., 212 1994], and spectral confidence levels were located using the robust AR(1) modelling of 213 median-smoothed spectra [Mann and Lees, 1996]. Wavelet analysis was performed using

214 Wavelet from Torrence and Compo [1998] and in order to study the presence and timing 
215 periodicities obtained in the single spectral analysis. Time-series correlation was performed

216 using the PearsonT programme [Mudelsee, 2003]. In PearsonT, the Pearson's correlation

217 coefficient is estimated employing a nonparametric stationary bootstrap confidence interval

218 with an average block length proportional to the maximum estimated persistence time of the

219 data [Mudelsee, 2003].

220 5. Results

\section{$221 \quad$ 5.1. RAPiD-17-5P (Iceland Basin)}

222 The sub-decadal $\overline{\text { SS }}$ near-bottom flow speed reconstruction for ISOW in the Iceland Basin from RAPiD-17-5P shows a particle size variability of 6-8 $\mu \mathrm{m}$ for the last 3000 years (Figure 3e). The $\overline{\mathrm{SS}}$ record shows the highest variability on a decadal timescale between $3000-2200$ years BP with a broad well-defined minimum in $\overline{\mathrm{SS}}$ occurring between 1850-1500 years BP with a low centered at 1750 years BP followed by a gradual steady decrease of $\sim 4.5 \mu \mathrm{m}$ since $\sim 1500$ years BP. Other marked slowdowns of ISOW occur at around 2250, 2050, 1250 and 950 yrs BP (Figure 3e).

Single spectrum and wavelet analyses were performed on the $18.6 \mathrm{yr}$ (minimum time-step) gaussian interpolated $\overline{\mathrm{SS}}$ records with a 56.9-yr window for RAPiD-17-5P. Cyclicities are found at 165 and 75 years at $>95 \%$ and $>90 \%$ Confidence Limit (CL), although wavelet analysis reveals that these cyclicities are not stationary throughout the record suggesting they are not a pervasive feature of the flow speed record (Supplementary Figure 1,2).

\subsection{RAPiD-35-COM (Eirik Drift)}

236 The near-bottom flow speed reconstruction for DSOW from RAPiD-35-COM (Eirik Drift)

237 shows a $\overline{\mathrm{SS}}$ variability of $\sim 7 \mu \mathrm{m}$, ranging in grain sizes between 19-26 $\mu \mathrm{m}$ over the last 4000 238 years (Figure 4a). The record shows persistent low $\overline{\mathrm{SS}}$ and relatively stable (decrease amplitude variability) between 2300-4000 years BP. At 2300 years BP the record shows a 
240 shift to higher amplitude variability (Figure 4a inset) with also faster flow speeds becoming

241 more prevalent towards the present. Additional centennial-scale lows in $\overline{\mathrm{SS}}$ are found at 242 1900-2100, 1100-1500 and 300-500 years BP (Figure 4a).

243 Single spectrum and wavelet analysis on the 45-year Gaussian smoothed $\overline{\mathrm{SS}}$ record from 244 RAPiD-35-COM reveal some periodicities at around 500 years, 280 years and 180 years, 245 with a hint of cyclicities at around 1500 years BP, however these cyclicities are not pervasive 246 through the last 4000 years (Supplementary Figure 3,4).

\section{Discussion}

6.1. Multidecadal to centennial changes in the ISOW strength over the last 3000 years

The $\overline{\mathrm{SS}}$ record from RAPiD-17-5P shows very defined and clear centennial to multidecadal oscillations (Figure 3e), however, it does not reveal a systematic relationship with previous reconstructions of climate variability derived from other sites within the North Atlantic, originally established from glacier advances and retreats by Denton and Kárlen [1973] and then synthesized and reviewed by Mayewski [2004] (Figure 3).

We use spectral analysis results to assess the possible presence of internal modes of variability of the ISOW vigour. Similarly to the recent study by Lohmann et al. [2014], the periodicities found in the 75-year domain could be related to the so-called Atlantic Multidecadal Oscillation (AMO). The AMO is defined as the interannual variability of sea

261 surface temperature in the North Atlantic between $0-70^{\circ} \mathrm{N}$ and have been observed to 262 oscillate with periodicities of 50-88 years [Schlesinger and Ramankutty, 1994]. Modelling studies have suggested that the AMO arises from internal variability in the strength of AMOC [Delworth and Mann, 2000; Knight et al., 2005], mostly via northward salt transport 
feedbacks that occur in the order of 50-60 years [Vellinga and $W u, 2004]$. Vellinga and $\mathrm{Wu}$ [2004] propose that a strong AMOC, enhances the transport of heat and salt to the higher latitudes creating a cross-equatorial sea surface temperature gradient that drives a northward migration of the ITCZ which will eventually freshen the tropical Atlantic and this freshwater anomaly will travel northwards and slowdown the AMOC. According to modelling work this process takes approximately 50-60 years [Vellinga and $\mathrm{Wu}, 2004$ ].

The potential for a relationship between the AMO and the ISOW strength suggested by the spectral characteristics has also been observed in other grain size reconstructions [Lohmann et al., 2014]. If correct, this would be evidence of the link between the strength of the AMOC and the AMO or more specifically the relationship between the sea surface temperatures within the Nordic Seas and the strength of the ISOW (as suggested by last millennium model results; Lohmann et al. [2014]). Nevertheless, the interpretation of the multidecadal cyclicities found in the $\overline{\mathrm{SS}}$ records from ISOW is difficult particularly as firstly the short length of the proxy reconstructions of the AMO [1600 and 1300 years AD, Gray et al., 2004; Mann et al., 2009, respectively] precludes a confident comparison with the ISOW vigour and also the interpolated time-step of the ISOW may lead to some aliasing at this frequency. Further detailed discussion is therefore not included in this paper.

\subsection{Long-term changes in the upstream ISOW vigour over the last 3000 years}

284 To interpret the reconstructed past changes in ISOW strength it is essential to understand what controls the vigour of ISOW transport over the GSR and how these factors may have varied in the past. To this end, the close location of RAPiD-17-5P to the Greenland-Scotland Ridge is advantageous, as it is more sensitive to the hydraulically controlled transport of ISOW entering the Atlantic Basin [Thornalley et al., 2013] than other sites located further downstream such as Gardar Drift [Bianchi and McCave, 1999; Ellison et al., 2006], which 
could potentially be modulated by Labrador Sea Water production because of entrainment and mixing processes [Boessenkool et al., 2007].

292 Therefore, variability in the strength of the ISOW recorded in RAPiD-17-5P could have resulted from changes in the density and the reservoir height of the ISOW source waters upstream of the GSR. The deep waters constrained north of the GSR in the Nordic Seas are mostly formed by winter cooling and densification of warm surface Atlantic inflow waters. Specifically, Norwegian Sea Deep Waters (NDSW), which is thought to be the main source waters for ISOW, comprises a mixture of intermediate waters formed in the Norwegian Sea mostly as a consequence of the cooling and densification of the warm salty Atlantic inflow waters and intermediate waters formed during the cyclonic-loop of the Atlantic inflow waters around the Nordic Seas and the Arctic Ocean [Mauritzen, 1996; Eldevik et al., 2009]. It is for this reason that past changes in the surface hydrography in the Nordic Seas may have a part in the strength of deep water formation.

304 The surface hydrography in the Nordic Seas broadly consists of the south flowing East

305 Greenland Current (EGC) in the west of the basin, which transports low-salinity Arctic waters along the East Greenland margin and on the eastern side of the basin by warm salty

307 Atlantic inflow waters flow as they flow northwards as the Norwegian Atlantic Current 308 (NwAC) (Figure 1). It is therefore possible, that the formation of NSDW was limited by the 309 volume and/or properties of Atlantic inflow or by an increase in polar waters reaching the 310 deep water formation sites. For instance, an increase of polar versus Atlantic waters in the

311 Norwegian Seas would likely result in an excess of freshwater at the surface which would 312 stratify the upper water column hence potentially inhibiting convection and decrease NSDW 313 formation. 
315 A number of Holocene surface proxy reconstructions of the NwAC (from the Norwegian

316 Sea- MD95-2011, Voring Plateau and the Barents Sea- PSh5159N) present discrepancies in

317 the long term trends for the last 3000 years [Calvo et al., 2002; Risebrobakken et al., 2003;

318 Andersen et al., 2004; Moros et al., 2004; Andersson et al., 2010; Risebrobakken et al.,

319 2010], and most of these reconstructions lack the high-temporal resolution in the RAPiD-17-

320 5P record, making direct comparison difficult. However, a high-resolution planktonic

321 foraminiferal $\delta^{18} \mathrm{O}$ record with good age-constraints from the NwAC [Sejrup et al., 2011],

322

323

324

325

326

327

328

329

330

331

332

333

334

335

336

337

338

339

reveals a similar decrease in temperature from 1750 years BP to present (Figure 3b), with a similar trend to the one found in the RAPiD-17-5P $\overline{\mathrm{SS}}$ record (Figure 3e). Ample evidence also suggests a Late Holocene trend towards a cold and sea ice laden EGC with an increase in the influence of polar waters and drift ice reaching North of Iceland via the East Icelandic Current (EIC), a branch of the EGC [Andrews et al., 1997; Jennings et al., 2002; Moros et al., 2006; Müller et al., 2012; Werner et al., 2013] and therefore potentially flowing into the Norwegian Sea (Figure 3c).

This millennial scale trend was probably associated with an ocean regime dominated by enhanced Arctic sea-ice production associated with a decline in summer insolation at these latitudes (Figure 3). The drift ice would have been transported into the Nordic Seas via the EGC. A Neoglacial increase in Arctic sea-ice and freshwater in the Norwegian Seas via an increase in the transport by the EGC and EIC, would have shoaled convection, decreasing the formation of NSDW as suggested by modelling studies [Renssen et al., 2005; Thornalley et $a l ., 2013]$. A reduction in NSDW formation would have driven a decrease in ISOW vigour as shown in the RAPiD-17-5P $\overline{\mathrm{SS}}$ near-bottom flow speed reconstruction from 1500 years BP onwards (Figure 3e). These millennial-scale changes in ISOW from RAPiD-17-5P are in broad agreement with lower temporal resolution reconstructions of ISOW vigour [Kissel et 
al., 2013; Thornalley et al., 2013]. However, in the higher temporal resolution of our record

341 we find that the Neoglacial trend may not have been as linear as previously suggested and it

342 was interrupted by centennial episodes of slower ISOW such as the period centered around 3431750 years BP, which is also evident in the Kissel et al. [2013] record. This feature indicates

344 that other processes, aside from a decrease in summer insolation (Figure 3a) may have also 345 played a role in the centennial scale-variability of the ISOW strength including feedbacks 346 either arising either from internal climate dynamics or external forcings. However, the ISOW

347 slowdown centered around 1750 years BP is not clearly evident in other North Atlantic 348 surface ocean records, possibly due to the lower temporal resolution of most marine archives.

349 Yet, temperature records from the Greenland Ice Sheet Project 2 (GISP2) do record a 350 temperature drop around this time [Alley, 2000; Kobashi et al., 2011] (Figure 3d), tentatively suggesting a linkage between a slowdown of ISOW and cooling in Greenland.

\subsection{Variability in the DSOW strength South of Greenland}

\subsubsection{Sortable Silt mean grain size variability recorded in the Eirik Drift}

355 Similar to RAPiD-17-5P, the centennial shifts in RAPiD-35-COM do not show any clear relationship with temperature reconstructions from other sites around the North Atlantic across this interval [Denton and Karlén, 1973; Mayewski, 2004] (Figure 4). Although Figure 4a shows a broad tentative correspondence of slower/faster flow speeds of DSOW with wellknown cold/warm intervals, this is not the case during the Little Ice Age.

\subsubsection{Source waters supplying DSOW: East Greenland Current versus North Icelandic Jet}

361 The DSOW is formed by a complex and varied mixture of water masses deriving from the

362 Arctic, Nordic Seas, re-circulating Atlantic waters and other minor water masses [Rudels et 363 al., 2002; Tanhua et al., 2005; Kohl et al., 2007; Dickson et al., 2008]. Consequently, the

364 variability of DSOW vigour could arise from changes in the relative contribution of its source 
waters and/or in the hydrographic properties of these. Over the last few decades many hydrographic and tracer studies have investigated the composition of DSOW, yet, it remains unclear which water masses are the primary contributors. Some studies have suggested that the DSOW is exclusively supplied by the EGC, which comprises a mixture of re-circulating Atlantic waters (Atlantic waters that have undergone transformation and densification via heat loss in and around the Nordic Seas) and polar waters formed in the Arctic and/or in the Greenland Sea [Swift and Aagaard, 1981; Strass et al., 1993; Mauritzen, 1996; Rudels et al., 2002; Jeansson et al., 2008; Eldevik et al., 2009]. Others have proposed that intermediate waters formed in the Iceland Sea as a result of winter cooling are the dominant constituent of DSOW [Swift et al., 1980; Jonsson, 1999; Jonsson and Valdimarsson, 2004; Vage et al., 2011]. These two contrasting suggestions have often been referred to as Atlantic and Polar sources of DSOW [Eldevik et al., 2009].

The $\overline{\mathrm{SS}}$ record from RAPiD-35-COM presents a gradual trend towards higher near-bottom flow speeds of DSOW from 2300 years BP to present with increased variance (Figure 4a). This trend, is consistent with previous low-resolution grain size and mineral composition results from the southwest Greenland Rise also indicating changes in DSOW around this time [Fagel et al., 2004]. Surface proxy records based on Ice Rafted Debris (IRD) counts, benthic foraminiferal assemblages and organic geochemistry along the East Greenland margin also reveal a consistent picture, indicating a progressive increase in sea ice and colder EGC for the last 3000-4000 years (Figure 4b,c) [Andrews et al., 1997; Jennings et al., 2002; Andersen et al., 2004; Moros et al., 2006; Müller et al., 2012; Werner et al., 2013]. A gradual increase in

387 the southern influence of polar waters reaching North Iceland has also been suggested by an 388 increase in terrigenous allochtonous quartz transported by drift ice by the EIC [Moros et al., 389 2006; Andrews, 2009] (Figure 4). The increase in the southward advection of polar waters, 
suggests either a gradual eastern shift of the polar front across the Nordic Seas and/or an

391 increase in the southward transport of polar waters within the EGC throughout the Late

392 Holocene. A concomitant increase in the volume transport of the EGC and DSOW vigour

393 (Figure 4a-c) would be in agreement with the concept of the EGC as a dominant water mass

394 source of DSOW [Rudels et al., 2002; Våge et al., 2013].

395

396 Deep ocean mooring studies have identified that the seasonal variability of the EGC upstream

397 of the Denmark Strait differs from that found in DSOW [Jonsson, 1999; Jonsson and 398 Valdimarsson, 2004]. As initially suggested by Swift et al. [1980], recent evidence strongly 399 supports the importance of intermediate waters formed by winter convection in the Iceland 400 Sea as important contributors $(\sim 50 \%)$ to the DSOW transports [Vage et al., 2011]. For 401 example, the recently discovered North Icelandic Jet (NIJ), is a narrow $15-20 \mathrm{~km}$-wide barotropic jet that flows from the Iceland Sea to the Denmark Strait along the Iceland Slope beneath the Atlantic inflow branch with a mean speed velocity of $40 \mathrm{~cm} / \mathrm{sec}$ following the $600 \mathrm{~m}$ isobath [Jonsson and Valdimarsson, 2004]. As demonstrated in model simulations, the transport and transformation of the warm salty waters from the North Iceland Irminger Current, a branch of the Atlantic inflow, Figure 1) into the Iceland Basin, plays a critical role in the formation of the NIJ [Vage et al., 2011]. However, Late Holocene reconstructions, based on foraminiferal and coccolithophore assemblages [Giraudeau et al., 2004; Ólafsdóttir et al., 2010; Jennings et al., 2011] show a decrease in the influence NIIC reaching North

410 Iceland for the last 4000 years. This is further supported by alkenone and diatom-based 411 temperature reconstructions from North Iceland [Jiang et al., 2002; Bendle and Rosell-Mele, 412 2007; Sicre et al., 2008b] (Figure 4d). Taken together, these studies consistently suggest a 413 gradual increase in the influence of polar waters relative to Atlantic waters reaching the North 414 Icelandic shelf over the last 3000 years. It is therefore difficult to reconcile an increased 
415 influence of fresher polar waters in the Iceland Sea promoting enhanced winter convection,

416 especially since modelling studies have demonstrated the key role of the inflow of Atlantic

417 waters in the preconditioning for open convection in the Iceland Sea [Vage et al., 2011].

418 We therefore argue that an enhanced supply and/or density of the EGC waters to the DSOW

419 is the most plausible explanation for the upstream changes that might have led to a

420 Neoglacial increase in the DSOW vigour as recorded in RAPiD-35-COM. It is possible that

421 the Arctic increase in sea ice formation and sea ice cover during the Neoglacial (as a response

422

423

424

425

426

427

428

430

431

432

433

434

435

436

437

438

439

to the decrease in summer insolation at high latitudes) could have led to an increase in the formation of dense Arctic waters via brine rejection processes [Rasmussen and Thomsen, 2014]. Furthermore, it has been proposed that the Mid to Late Holocene was a transition towards a weakened state of the North Atlantic Oscillation (NAO) like atmospheric pattern in the Nordic Seas [Rimbu et al., 2003]. This atmospheric configuration may have promoted the southward transport of EGC waters (Dickson 2000). However, changes in the regional atmospheric circulation over the Neoglaciation remain largely unresolved due to the lack of consistent atmospheric proxy data [e.g. Mayewski et al., 1997; Nesje et al., 2001; Lamy et al., 2006; Olsen et al., 2012; Jackson et al., 2005]. Alternatively, the increase in the vigour of DSOW over the last 2300 years, may have instead been caused by downstream processes.

\subsubsection{Downstream entrainment processes of DSOW}

The overflow transport is also driven by the cross-sill density gradient and the hydrography of the water masses lying above the overflows once they enter the Atlantic Basin. Consequently, past changes in the density of the downstream water masses such as SPMW and LSW may also have affected the vigour of the DSOW. Hydrographic transects show that, during periods of reduced (enhanced) LSW formation, the density and volume of this water mass in the Irminger Basin is decreased (increased). A comparison of the millennial-scale 
440 variability of the surface conditions in the Eastern Labrador Sea highlight a millennial-scale

441 cooling of the IC perhaps indicating a weakening in the SPG circulation over the last 2250-

4423000 years BP and more influence of polar versus Atlantic waters in the WGC [Perner et al.,

443 2011]. This trend is similar to the one recorded in the DSOW vigour towards higher speeds.

444 A Late Holocene decrease in LSW formation (and hence density) would have led to an

445 increase in the cross-ridge density gradient, thereby driving a faster transport of DSOW into

446 the Atlantic Basin, which in turn would also promote entrainment and therefore a greater

447 volume of DSOW.

449 This finding is in agreement with observational data [Dickson et al., 1996] that have 450 suggested the presence of an antiphased 'see-saw' of deep water formation between the convection centres of the Labrador and Greenland Sea. The relationship has been explained to occur through the opposing impacts of atmospheric circulation in each of the convective centres [Dickson et al., 1996]. This seminal work by Dickson et al. (1996) concluded that during a positive North Atlantic Oscillation (NAO) state the strengthening of the westerlies (more zonal atmospheric circulation) over the North Atlantic promoted heat loss and deep convection in the Labrador Sea. Conversely, during a negative NAO state the enhanced northerlies (more meridional atmospheric and surface circulation in the Nordic SeasBlinheim [2000]) aided the delivery of polar waters via the EGC into the SPG, thereby inhibiting convection in the Labrador Sea but enhancing it in the Greenland Sea. However,

460 during the Neoglaciation, proxy work from the Fram Strait has suggested an expansion of the sea ice into the Greenland Sea [Müller et al., 2012; Werner et al., 2013], which means that freshwater forcing deriving from an increase in Arctic sea ice export might also have been a dominant control on convection in the Greenland Sea. 


\subsubsection{Summary of DSOW flow variability}

466 As illustrated above, our current knowledge of the causes of transport variability of DSOW in

467 the modern is still very limited, an issue which complicates our interpretation of the near468 bottom flow speed of DSOW in the past. From the options outlined above it is hard to discern 469 which one was the dominant mechanism in governing the millennial trend towards an increased vigour of DSOW from about $\sim 2300$ years BP. From the evidence presented, we conclude that upstream changes in the transport and constituents of the EGC and/or a reduction in the LSW formation were the most likely candidates for the Late Holocene strengthening of DSOW. We can additionally conclude that from the evidence presented here it is unlikely that increased NIIC reaching the Iceland Sea had control on the centennial to millennial variability of DSOW. The proposed changes in the Neoglacial ocean conditions were chiefly governed by the insolation-driven increase in Arctic sea ice production and potential changes in atmospheric circulation.

\subsection{Potential antiphasing of the Nordic Overflows}

479 The relationship between the vigour of ISOW and DSOW is yet to be fully established. 480 Modelling studies have frequently proposed an antiphasing of the volume transport between these overflows over the GSR, caused by the differing effects of atmospheric forcing on the deep water formation at the different convection sites in the Nordic Seas which supply the overflows [Biastoch et al., 2003; Kohl, 2010; Serra et al., 2010; Sandø et al., 2012].

484 Nonetheless, this relationship has not yet been clearly observed in the instrumental record. 485 The observed weakening of DSOW [Macrander et al., 2005] and strengthening of ISOW 486 [Hansen and Osterhus, 2007] in 2000 has been used as evidence for this relationship [Kohl et al., 2007], but there is yet no convincing observational evidence for this co-variance of the overflows. 
490 A visual comparison of the near-bottom flow speed reconstructions from ISOW and DSOW

491 strongly suggests an antiphased relationship between the two records (Figure 5). Indeed, the

492 normalised 45-year Gaussian interpolated $\overline{\mathrm{SS}}$ records from ISOW (RAPiD-17-5P) and

493 DSOW (RAPiD-35-COM) shows a Pearson Correlation of -0.417 with a $95 \%$ confidence

494 interval of $-0.595 ;-0.182$ (note: this correlation coefficient could be increased if these records

495 were tied within their respective age errors to one another) (Figure 5). These findings suggest

496 anti-phased behaviour in the vigour of the overflows east and west of Iceland on a millennial-

497 scale. Although it is not possible to investigate the potential compensation in the cross-ridge

498 volume transport of the overflows caused by this antiphasing, these results are in agreement

499 with numerous modelling results [Biastoch et al., 2003; Kohl, 2010; Serra et al., 2010; Sandø

500 et al., 2012]. Initially it was suggested that an increase in wind-stress curl north of Iceland

501 steers the circulation of waters to the west of Iceland enhancing DSOW transport while

502 decreasing the outflow through the Faroe Bank Channel [Biastoch et al., 2003]. However,

503 recent modelling studies propose that this anti-correlated behaviour of the overflows stems

504 from a switch between differently sourced water masses supplying the overflows as a response to wind-stress curl changes around Iceland and in the Nordic Seas (which is closely

506 dependent on the NAO state) [Kohl, 2010; Serra et al., 2010]. The mechanism invoking the

507 re-direction of the surface waters east and west of Iceland via wind-stress forcing is probably

508 of more relevance to DSOW variability on annual to shorter time-scales whereas upstream

509 changes in the site of overflow formation are more likely the causes for longer time-scale

510 variability [Kohl et al., 2007].

\section{7. Conclusions}

512 In this paper we have presented the first subdecadal to decadal reconstructions of the vigour

513 of the two Nordic Overflows (ISOW and the DSOW) for the last 3000-4000 years. The

514 results do not show a consistent change in the strength of either of the Nordic Overflows 
515 during the well-known centennial climate change events that have been commonly found in

516 the North Atlantic region. Our findings therefore suggest that contrary to previous 517 suggestions, this crucial component of the deep limb of the AMOC was potentially unrelated 518 to the centennial scale climate variability over the Late Holocene [Bianchi and McCave, 519 1999]. It is therefore possible that if in fact there is a link between AMOC strength changes 520 and these climatic events, it would have likely involved the formation of deep waters in the Labrador Sea; LSW [Moffa-Sanchez et al., 2014b]. However, a consistent millennial pattern is found in the two reconstructions: a slower ISOW from 1500 years BP to present and a faster DSOW from 2300 years BP. We propose that these millennial trends were caused by the surface alteration of the hydrography and atmospheric re-organisation in the Arctic and

525 Nordic Seas as a response to the decrease in summer Northern Hemisphere insolation through the Neoglaciation. A comparison of the overflow strength east and west of Iceland reveals a striking co-variability. Modelling studies have repeatedly reported an antiphased behaviour of the overflows but evidence for this has so far been limited. As suggested from the model results, it is possible that this antiphased behaviour was driven by atmospheric changes

530 switching the deep water formation sites that contribute to each of the overflows. The antiphased behaviour of the overflows on multicentennial to millennial timescales could allow for the compensation of the overflows east and west of Iceland, such that there was perhaps little effect on the net transport of deep waters of waters feeding the deep limb of the AMOC

534 over the late Holocene.

\section{Figure Captions}

536 Figure 1. Bathymetric map of the Nordic Seas and the North Atlantic indicating the location 537 of RAPiD-17-5P and RAPiD-35-COM (black filled circles indicate the core locations used in this study). Black dashed fine lines indicate the Greenland-Scotland Ridge. Dark blue arrows represent the simplified deep ocean circulation of the Nordic Sea Overflows, ISOW and 
540 DSOW and DWBC. Spirals indicate the sites of open ocean convection in the Nordic Seas,

541 which feed the Nordic Overflows. The surface ocean circulation is represented by the dashed

542 arrows, the pink indicating waters that originate from the North Atlantic Current (NAC), the

543 Norwegian Atlantic Current (NwAC) and the light blue represent the polar-derived currents

544 such as the East Greenland Current (EGC) and the East Icelandic Current (EIC). Base map 545 adapted from Ocean Data View [Schlitzer, 2014].

547 Figure 2. Core-chronology for RAPiD-35-14P based on ten calibrated radiocarbon dates 548 (filled black circles). The age-model was constructed using a bayesian age-model 549 programme; BChron [Haslett and Parnell, 2008]. The light grey shaded area indicates the $55095 \%$ probability error within the age model calculated in BChron. The light blue vertical band indicates the area where the data from the box-core RAPiD-35-25B (Moffa-Sanchez et al. 2014b) was used and spliced.

554 Figure 3. (a) Insolation at $60^{\circ} \mathrm{N}$, (b) $\delta^{18} \mathrm{O}$ measurements on Neogloboquadrina dextral which 555 are indicative of sea surface temperatures [Sejrup et al., 2011] (c) \% Quartz recorded from the North Icelandic shelf [Moros et al., 2006], (d) Greenland Ice Sheet Project 2 temperature reconstructions from Greenland [Alley et al., 2000], (e) $\overline{\mathrm{SS}}$ measurements from RAPiD-175P (this study). Inset map shows the colour-coded core locations of the records presented in the graph. Red and blue horizontal bars indicate the warm and cold periods respectively in the circum-North Atlantic [Mayewski, 2004]. Grey vertical shaded areas mark the time periods were $\overline{\mathrm{SS}}$ values were below the average record values.

563 Figure 4. (a) Near-bottom flow speed vigour of DSOW ( $\overline{\mathrm{SS}}$ measurements from RAPiD-35-

564 COM-this study) (b) Number of IRD grains $>2 \mathrm{~mm}$ from the East Greenland Coast [Jennings 
et al., 2002], (c) \% quartz from the North Icelandic shelf [Moros et al., 2006], (d) alkenone-

based August Sea Surface Temperatures (SST) from North Iceland [Sicre et al., 2008a,

2008b]. Arrows highlight the millennial-scale trends. Inset map shows the colour coded core

locations of the proxy reconstructions presented in the figure. Red and blue horizontal bars

mark the warm and cold periods respectively in the circum-North Atlantic [Mayewski, 2004].

Grey vertical shaded areas mark the time periods were $\overline{\mathrm{SS}}$ values were below average.

Figure 5. Comparison between the $\overline{\mathrm{SS}}$ records from DSOW (RAPiD-35-COM) and ISOW

(RAPiD-17-5P) in black and red respectively, which reveals antiphasing of the near-bottom

flow speeds for the last 3000 years. Lower panels normalised 45-gaussian smoothed $\overline{\mathrm{SS}}$ data

from ISOW and DSOW changes with time (left), versus each other (right).

\section{Acknowledgements}

578

579

580
We thank the crew of $R V$ Charles Darwin 159. We also thank the insightful and careful comments of two anonymous reviewers. The radiocarbon dating was supported by funding from the National Environment Research Countil U.K. P.M. and I.H. gratefully acknowledge the support of the Climate Change Consortium of Wales (www.c3wales.org).

\section{References}

Van Aken, H. M., and G. Becker (1996), Hydrography and through-flow in the north-eastern North Atlantic Ocean: the NANSEN project, Prog. Oceanogr., 38(4), 297-346, doi:10.1016/s0079-6611(97)00005-0.

Van Aken, H. M. (1995), HYDROGRAPHIC VARIABILITY IN THE BOTTOM LAYER OF THE ICELAND BASIN, J. Phys. Oceanogr., 25(7), 1716-1722, doi:10.1175/1520-0485(1995)025<1716:hvitbl $>2.0$.co;2.

Alley, R. B. (2000), The Younger Dryas cold interval as viewed from central Greenland, Quat. Sci. Rev., 19(1-5), 213-226, doi:10.1016/S0277-3791(99)00062-1. 
Andersen, C., N. Koç, A. Jennings, and J. T. Andrews (2004), Nonuniform response of the major surface currents in the Nordic Seas to insolation forcing: Implications for the Holocene climate variability, Paleoceanography, 19(2), PA2003, doi:10.1029/2002pa000873.

Andersson, C., F. S. R. Pausata, E. Jansen, B. Risebrobakken, and R. J. Telford (2010), Holocene trends in the foraminifer record from the Norwegian Sea and the North Atlantic Ocean, Clim. Past, 6(2), 179-193.

Andrews, J. T. (2009), Seeking a Holocene drift ice proxy: Non-clay mineral variations from the SW to N-central Iceland shelf: Trends, regime shifts, and periodicities, J. Quat. Sci., 24(7), 664-676, doi:10.1002/jqs.1257.

Andrews, J. T., L. M. Smith, R. Preston, T. Cooper, and A. E. Jennings (1997), Spatial and temporal patterns of iceberg rafting (IRD) along the East Greenland margin, ca. $68^{\circ} \mathrm{N}$, over the last 14 cal.ka, J. Quat. Sci., 12(1), 1-13.

Bendle, J. A. P., and A. Rosell-Mele (2007), High-resolution alkenone sea surface temperature variability on the North Icelandic Shelf: implications for Nordic Seas palaeoclimatic development during the Holocene, Holocene, 17(1), 9-24, doi:10.1177/0959683607073269.

Bianchi, G. G., and I. N. McCave (1999), Holocene periodicity in North Atlantic climate and deep-ocean flow south of Iceland, Nature, 397(6719), 515-517, doi:10.1038/17362.

Bianchi, G. G., and I. N. McCave (2000), Hydrography and sedimentation under the deep western boundary current on Björn and Gardar Drifts, Iceland Basin, Mar. Geol., 165(1-4), 137-169, doi:10.1016/s0025-3227(99)00139-5.

Bianchi, G. G., I. R. Hall, I. N. McCave, and L. Joseph (1999), Measurement of the sortable silt current speed proxy using the Sedigraph 5100 and Coulter Multisizer IIe: Precision and accuracy, Sedimentology, 46(6), 1001-1014.

Biastoch, A., R. H. Kase, and D. B. Stammer (2003), The sensitivity of the GreenlandScotland Ridge overflow to forcing changes, J. Phys. Oceanogr., 33(11), 2307-2319, doi:10.1175/1520-0485(2003)033<2307:tsotgr $>2.0$.co;2.

Blindheim, J., V. Borovkov, B. Hansen, S. A. Malmberg, W. R. Turrell, and S. Osterhus (2000), Upper layer cooling and freshening in the Norwegian Sea in relation to atmospheric forcing, Deep-Sea Res. Part-Oceanogr. Res. Pap., 47(4), 655-680, doi:10.1016/s0967-0637(99)00070-9.

Boessenkool, K. P., I. R. Hall, H. Elderfield, and I. Yashayaev (2007), North Atlantic climate and deep-ocean flow speed changes during the last 230 years, Geophys. Res. Lett., 34(13), L13614, doi:10.1029/2007g1030285.

Born, A., A. Levermann, and J. Mignot (2009), Sensitivity of the Atlantic Ocean circulation to a hydraulic overflow parameterisation in a coarse resolution model: Response of the subpolar gyre, Ocean Model., 27(3-4), 130-142, doi:10.1016/j.ocemod.2008.11.006. 
646

647

648

649

650

651

652

653

654

655

656

657

658

659

660

661

662

663

664

665

666

667

668

Calvo, E., J. O. Grimalt, and E. Jansen (2002), High resolution U(37)(K) sea surface temperature reconstruction in the Norwegian Sea during the Holocene, Quat. Sci. Rev., 21(12-13), 1385-1394, doi:10.1016/s0277-3791(01)00096-8.

Delworth, T. L., and M. E. Mann (2000), Observed and simulated multidecadal variability in the Northern Hemisphere, Clim. Dyn., 16(9), 661-676, doi:10.1007/s003820000075.

Denton, G. H., and W. Karlén (1973), Holocene climatic variations-Their pattern and possible cause, Quat. Res., 3(2), 155-205, doi:10.1016/0033-5894(73)90040-9.

Dickson, B., J. Meincke, and P. Rhines (2008), Arctic-Subarctic Ocean Fluxes Defining the Role of the Northern Seas in Climate, The Inflow of Atlantic Water, Heat, and Salt to the Nordic Seas Across the Greenland-Scotland Ridge, Springer Netherlands.

Dickson, R., J. Lazier, J. Meincke, P. Rhines, and J. Swift (1996), Long-term coordinated changes in the convective activity of the North Atlantic, Prog. Oceanogr., 38(3), 241295.

Dickson, R. R., and J. Brown (1994), The production of North Atlantic Deep Water: Sources, rates, and pathways, J Geophys Res, 99(C6), 12319-12341, doi:10.1029/94jc00530.

Eldevik, T., J. E. O. Nilsen, D. Iovino, K. Anders Olsson, A. B. Sando, and H. Drange (2009), Observed sources and variability of Nordic seas overflow, Nat. Geosci., 2(6), 406-410, doi:10.1038/ngeo518.

Ellison, C. R. W., M. R. Chapman, and I. R. Hall (2006), Surface and Deep Ocean Interactions During the Cold Climate Event 8200 Years Ago, Science, 312(5782), 1929-1932, doi:10.1126/science.1127213.

Fagel, N., C. Hillaire-Marcel, M. Humblet, R. Brasseur, D. Weis, and R. Stevenson (2004), $\mathrm{Nd}$ and $\mathrm{Pb}$ isotope signatures of the clay-size fraction of Labrador Sea sediments during the Holocene: Implications for the inception of the modern deep circulation pattern, Paleoceanography, 19(3), PA3002, doi:10.1029/2003PA000993.

Fogelqvist, E., J. Blindheim, T. Tanhua, S. Osterhus, E. Buch, and F. Rey (2003), GreenlandScotland overflow studied by hydro-chemical multivariate analysis, Deep-Sea Res. Part-Oceanogr. Res. Pap., 50(1), 73-102, doi:10.1016/s0967-0637(02)00131-0.

Giraudeau, J., A. E. Jennings, and J. T. Andrews (2004), Timing and mechanisms of surface and intermediate water circulation changes in the Nordic Seas over the last 10,000 years: a view from the North Iceland shelf, Quat. Sci. Rev., 23(20-22), 2127-2139, doi:10.1016/j.quascirev.2004.08.011.

Gray, S. T., L. J. Graumlich, J. L. Betancourt, and G. T. Pederson (2004), A tree-ring based reconstruction of the Atlantic Multidecadal Oscillation since 1567 AD, Geophys. Res. Lett., 31(12), doi:10.1029/2004g1019932.

Hall, I. R., G. G. Bianchi, and J. R. Evans (2004), Centennial to millennial scale Holocene climate-deep water linkage in the North Atlantic, Quat. Sci. Rev., 23(14-15), 15291536. 
682

683

684

685

686

687

688

689

690

691

692

693

694

695

696

697

698

699

700

701

702

703

704

705

706

Hansen, B., and S. Osterhus (2007), Faroe Bank Channel overflow 1995-2005, Prog. Oceanogr., 75(4), 817-856, doi:10.1016/j.pocean.2007.09.004.

Hansen, B., W. R. Turrell, and S. Osterhus (2001), Decreasing overflow from the Nordic seas into the Atlantic Ocean through the Faroe Bank channel since 1950, Nature, 411(6840), 927-930, doi:10.1038/35082034.

Hansen, B., S. Østerhus, D. Quadfasel, and W. Turrell (2004), Already the Day After Tomorrow?, Science, 305(5686), 953-954, doi:10.1126/science.1100085.

Hansen, B., H. Hátún, R. Kristiansen, S. M. Olsen, and S. Østerhus (2010), Stability and forcing of the Iceland-Faroe inflow of water, heat, and salt to the Arctic, ., 6, 10131026, doi:10.5194/os-6-1013-2010, 2010., , 6, 1013-1026.

Haslett, J., and A. Parnell (2008), A simple monotone process with application to radiocarbon-dated depth chronologies, J. R. Stat. Soc. Ser. C Appl. Stat., 57(4), 399418, doi:10.1111/j.1467-9876.2008.00623.x.

Holliday, N. P., S. Bacon, J. Allen, and E. L. McDonagh (2009), Circulation and transport in the western boundary currents at Cape Farewell, Greenland, J. Phys. Oceanogr., 39(8), 1854-1870, doi:10.1175/2009JPO4160.1.

Jackson, M. G., N. Oskarsson, R. G. Trønnes, J. F. McManus, D. W. Oppo, K. Grönvold, S. R. Hart, and J. P. Sachs (2005), Holocene loess deposition in Iceland: Evidence for millennial-scale atmosphere-ocean coupling in the North Atlantic, Geology, 33(6), 509-512.

Jeansson, E., S. Jutterstroem, B. Rudels, L. G. Anderson, K. A. Olsson, E. P. Jones, W. M. Smethie, and J. H. Swift (2008), Sources to the East Greenland Current and its contribution to the Denmark Strait Overflow, Prog. Oceanogr., 78(1), 12-28, doi:10.1016/j.pocean.2007.08.031.

Jennings, A., J. Andrews, and L. Wilson (2011), Holocene environmental evolution of the SE Greenland Shelf North and South of the Denmark Strait: Irminger and East Greenland current interactions, Quat. Sci. Rev., 30(7-8), 980-998.

Jennings, A. E., K. L. Knudsen, M. Hald, C. V. Hansen, and J. T. Andrews (2002), A midHolocene shift in Arctic sea-ice variability on the East Greenland Shelf, Holocene, 12(1), 49-58.

Jiang, H., M. S. Seidenkrantz, K. L. Knudsen, and J. Eiriksson (2002), Late-Holocene summer sea-surface temperatures based on a diatom record from the north Icelandic shelf, Holocene, 12(2), 137-147, doi:10.1191/0959683602h1529rp.

Jonsson, S. (1999), The circulation in the northern part of the Denmark Strait and its variability, CES CM, 9.

Jonsson, S., and H. Valdimarsson (2004), A new path for the Denmark Strait overflow water from the Iceland Sea to Denmark Strait, Geophys. Res. Lett., 31(3), L03305, doi:10.1029/2003g1019214. 
Kissel, C., A. Van Toer, C. Laj, E. Cortijo, and E. Michel (2013), Variations in the strength of the North Atlantic bottom water during Holocene, Earth Planet. Sci. Lett., 369 370(0), 248-259, doi:10.1016/j.eps1.2013.03.042.

Knight, J. R., R. J. Allan, C. K. Folland, M. Vellinga, and M. E. Mann (2005), A signature of persistent natural thermohaline circulation cycles in observed climate, Geophys. Res. Lett., 32(20), doi:10.1029/2005g1024233.

Kobashi, T., K. Kawamura, J. P. Severinghaus, J. Barnola, T. Nakaegawa, B. M. Vinther, S. J. Johnsen, and J. E. Box (2011), High variability of Greenland surface temperature over the past 4000 years estimated from trapped air in an ice core, Geophys. Res. Lett., 38(21).

Kohl, A. (2010), Variable source regions of Denmark Strait and Faroe Bank Channel overflow waters, Tellus Ser. -Dyn. Meteorol. Oceanogr., 62(4), 551-568, doi:10.1111/j.1600-0870.2010.00454.x.

Kohl, A., R. H. Kaese, D. Stammer, and N. Serra (2007), Causes of changes in the Denmark strait overflow, J. Phys. Oceanogr., 37(6), 1678-1696, doi:10.1175/jpo3080.1.

Kuhlbrodt, T., A. Griesel, M. Montoya, A. Levermann, M. Hofmann, and S. Rahmstorf (2007), On the driving processes of the Atlantic meridional overturning circulation, Rev. Geophys., 45(2), RG2001, doi:10.1029/2004RG000166.

Lamy, F., H. W. Arz, G. C. Bond, A. Bahr, and J. Pätzold (2006), Multicentennial-scale hydrological changes in the Black Sea and northern Red Sea during the Holocene and the Arctic/North Atlantic Oscillation, Paleoceanography, 21(1), PA1008, doi:10.1029/2005PA001184.

Lohmann, K., J. Mignot, H. R. Langehaug, J. H. Jungclaus, D. Matei, O. H. Otterå, Y. Gao, T. L. Mjell, U. Ninnemann, and H. F. Kleiven (2014), Using simulations of the last millennium to understand climate variability seen in paleo-observations: similar variation of Iceland-Scotland overflow strength and Atlantic Multidecadal Oscillation, Clim Past Discuss, 10(4), 3255-3302, doi:10.5194/cpd-10-3255-2014.

Macrander, A., U. Send, H. Valdimarsson, S. Jónsson, and R. H. Käse (2005), Interannual changes in the overflow from the Nordic Seas into the Atlantic Ocean through Denmark Strait, Geophys. Res. Lett., 32(6), L06606, doi:10.1029/2004g1021463.

Mann, M. E., and J. M. Lees (1996), Robust estimation of background noise and signal detection in climatic time series, Clim. Change, 33(3), 409-445, doi:10.1007/bf00142586.

Mann, M. E., Z. Zhang, S. Rutherford, R. S. Bradley, M. K. Hughes, D. Shindell, C. Ammann, G. Faluvegi, and F. Ni (2009), Global Signatures and Dynamical Origins of the Little Ice Age and Medieval Climate Anomaly, Science, 326(5957), 1256-1260, doi:10.1126/science.1177303.

Mauritzen, C. (1996), Production of dense overflow waters feeding the North Atlantic across the Greenland-Scotland Ridge. Part 1: Evidence for a revised circulation scheme, Deep Sea Res. Part Oceanogr. Res. Pap., 43(6), 769-806, doi:10.1016/09670637(96)00037-4. 
Mayewski, P. A. (2004), Holocene climate variability, Quat Res, 62, 243-255, doi:10.1016/j.yqres.2004.07.001.

Mayewski, P. A., L. D. Meeker, M. S. Twickler, S. Whitlow, Y. Qinzhao, W. Berry Lyons, and M. Prentice (1997), Major features and forcing of high-latitude Northern Hemisphere atmospheric circulation using a 110000 -year-long glaciochemical series, J. Geophys. Res., 102(C12), 26345-26366.

McCave, I. N. (2004), CD159 Cruise Report.

McCave, I. N., and I. R. Hall (2006), Size sorting in marine muds: Processes, pitfalls, and prospects for paleoflow-speed proxies, Geochem. Geophys. Geosystems, 7(10), Q10N05, doi:10.1029/2006gc001284.

McCave, I. N., B. Manighetti, and S. G. Robinson (1995), Sortable Silt and Fine Sediment Size/Composition Slicing: Parameters for Palaeocurrent Speed and Palaeoceanography, Paleoceanography, 10(3), 593-610, doi:10.1029/94pa03039.

Meincke, J. (1983), The Modern Current Regime Across the Greenland-Scotland Ridge, in Structure and Development of the Greenland-Scotland Ridge, vol. 8, edited by M. P. Bott, S. Saxov, M. Talwani, and J. Thiede, pp. 637-650, Springer US.

Moffa-Sanchez, P., A. Born, I. R. Hall, and D. J. R. Thornalley (2014a), Solar forcing of North Atlantic surface temperature and salinity over the last millennium, Nat. Geosci.

Moffa-Sanchez, P., I. R. Hall, S. Barker, D. J. R. Thornalley, and I. Yashayaev (2014b), Surface changes in the Eastern Labrador Sea around the onset of the Little Ice Age, Paleoceanography, doi:10.1002/2013PA002523.

Moros, M., K. Emeis, B. Risebrobakken, I. Snowball, A. Kuijpers, J. McManus, and E. Jansen (2004), Sea surface temperatures and ice rafting in the Holocene North Atlantic: climate influences on northern Europe and Greenland, Quat. Sci. Rev., 23(20-22), 2113-2126, doi:10.1016/j.quascirev.2004.08.003.

Moros, M., J. T. Andrews, D. D. Eberl, and E. Jansen (2006), Holocene history of drift ice in the northern North Atlantic: Evidence for different spatial and temporal modes, Paleoceanography, 21(2), doi:10.1029/2005PA001214.

Mudelsee, M. (2003), Estimating Pearson's correlation coefficient with bootstrap confidence interval from serially dependent time series, Math. Geol., 35(6), 651-665.

Müller, J., K. Werner, R. Stein, K. Fahl, M. Moros, and E. Jansen (2012), Holocene cooling culminates in sea ice oscillations in Fram Strait, Quat. Sci. Rev., 47(0), 1-14, doi:10.1016/j.quascirev.2012.04.024.

Nesje, A., J. A. Matthews, S. O. Dahl, M. S. Berrisford, and C. Andersson (2001), Holocene glacier fluctuations of Flatebreen and winter-precipitation changes in the Jostedalsbreen region, western Norvay, based on glaciolacustrine sediment records, The Holocene, 11(3), 267-280. 
Ólafsdóttir, S., A. E. Jennings, A. Geirsdóttir, J. Andrews, and G. H. Miller (2010), Holocene variability of the North Atlantic Irminger current on the south- and northwest shelf of Iceland, Mar. Micropaleontol., 77(3-4), 101-118.

Olsen, J., N. J. Anderson, and M. F. Knudsen (2012), Variability of the North Atlantic Oscillation over the past 5,200 years, Nat. Geosci, 5(11), 808-812.

Olsen, S. M., B. Hansen, D. Quadfasel, and S. Osterhus (2008), Observed and modelled stability of overflow across the Greenland-Scotland ridge, Nature, 455(7212), 519522.

Pardoiguzquiza, E., M. Chicaolmo, and F. J. Rodrigueztovar (1994), CYSTRATI - A COMPUTER-PROGRAM FOR SPECTRAL-ANALYSIS OF STRATIGRAPHIC SUCCESSIONS, Comput. Geosci., 20(4), 511-584, doi:10.1016/00983004(94)90080-9.

Parnell, A. C., C. E. Buck, and T. K. Doan (2011), A review of statistical chronology models for high-resolution, proxy-based Holocene palaeoenvironmental reconstruction, Quat. Sci. Rev., 30(21-22), 2948-2960, doi:10.1016/j.quascirev.2011.07.024.

Perner, K., M. Moros, J. M. Lloyd, A. Kuijpers, R. J. Telford, and J. Harff (2011), Centennial scale benthic foraminiferal record of late Holocene oceanographic variability in Disko Bugt, West Greenland, Quat. Sci. Rev., 30(19-20), 2815-2826.

Price, J. F., and M. O. Baringer (1994), OUTFLOWS AND DEEP-WATER PRODUCTION BY MARGINAL SEAS, Prog. Oceanogr., 33(3), 161-200, doi:10.1016/00796611(94)90027-2.

Rahmstorf, S., J. E. Box, G. Feulner, M. E. Mann, A. Robinson, S. Rutherford, and E. J. Schaffernicht (2015), Exceptional twentieth-century slowdown in Atlantic Ocean overturning circulation, Nat. Clim Change, 5(5), 475-480.

Rasmussen, T. L., and E. Thomsen (2014), Brine formation in relation to climate changes and ice retreat during the last 15,000 years in Storfjorden, Svalbard, $76-78^{\circ} \mathrm{N}$, Paleoceanography, 29(10), 2014PA002643, doi:10.1002/2014PA002643.

Reimer, P. J. et al. (2013), IntCal13 and Marine13 Radiocarbon Age Calibration Curves 050,000 Years cal BP, Radiocarb. Vol 55 No 42013.

Renssen, H., H. Goosse, and T. Fichefet (2005), Contrasting trends in North Atlantic deepwater formation in the Labrador Sea and Nordic Seas during the Holocene, Geophys. Res. Lett., 32(8), L08711, doi:10.1029/2005GL022462.

Rimbu, N., G. Lohmann, J. H. Kim, H. W. Arz, and R. Schneider (2003), Arctic/North Atlantic Oscillation signature in Holocene sea surface temperature trends as obtained from alkenone data, Geophys. Res. Lett., 30(6), 1280, doi:10.1029/2002g1016570.

Risebrobakken, B., E. Jansen, C. Andersson, E. Mjelde, and K. Hevrøy (2003), A highresolution study of Holocene paleoclimatic and paleoceanographic changes in the Nordic Seas, Paleoceanography, 18(1), 17-1. 
Risebrobakken, B., M. Moros, E. V. Ivanova, N. Chistyakova, and R. Rosenberg (2010), Climate and oceanographic variability in the SW Barents Sea during the Holocene, Holocene, 20(4), 609-621, doi:10.1177/0959683609356586.

Rossby, T. (1996), The North Atlantic Current and surrounding waters: At the crossroads, Rev. Geophys., 34(4), 463-481, doi:10.1029/96RG02214.

Rudels, B., E. Fahrbach, J. Meincke, G. Budeus, and P. Eriksson (2002), The East Greenland Current and its contribution to the Denmark Strait overflow, Ices J. Mar. Sci., 59(6), 1133-1154, doi:10.1006/jmsc.2002.1284.

Sandø, A. B., J. E. Ø. Nilsen, T. Eldevik, and M. Bentsen (2012), Mechanisms for variable North Atlantic-Nordic seas exchanges, J. Geophys. Res. Oceans, 117(C12), C12006, doi:10.1029/2012JC008177.

Schlesinger, M. E., and N. Ramankutty (1994), An oscillation in the global climate system of period 65-70 years, Nature, 367(6465), 723-726, doi:10.1038/367723a0.

Schlitzer, R. (2014), Ocean Data View, Ocean Data View, http://odv.awi.de.

Sejrup, H. P., H. Haflidason, and J. T. Andrews (2011), A Holocene North Atlantic SST record and regional climate variability, Quat. Sci. Rev., 30(21-22), 3181-3195, doi:10.1016/j.quascirev.2011.07.025.

Serra, N., R. H. KÄSe, A. KÖH1, D. Stammer, and D. Quadfasel (2010), On the lowfrequency phase relation between the Denmark Strait and the Faroe-Bank Channel overflows, Tellus A, 62(4), 530-550, doi:10.1111/j.1600-0870.2010.00445.x.

Sicre, M. A., J. Jacob, U. Ezat, S. Rousse, C. Kissel, P. Yiou, J. Eiríksson, K. L. Knudsen, E. Jansen, and J. L. Turon (2008a), Decadal variability of sea surface temperatures off North Iceland over the last 2000 years, Earth Planet. Sci. Lett., 268(1-2), 137-142, doi:10.1016/j.eps1.2008.01.011.

Sicre, M.-A., P. Yiou, J. Eiriksson, U. Ezat, E. Guimbaut, I. Dahhaoui, K.-L. Knudsen, E. Jansen, and J.-L. Turon (2008b), A 4500-year reconstruction of sea surface temperature variability at decadal time-scales off North Iceland, Quat. Sci. Rev., 27(21-22), 2041-2047, doi:10.1016/j.quascirev.2008.08.009.

Stocker, T. F., D. Qin, G.-K. Plattner, M. Tignor, S. K. Allen, A. Boschung, A. Nauels, Y. Xia, V. Bex, and P. M. Midgley (2013), IPCC, 2013: Climate Change 2013: The Physical Science Basis. Contribution of Working Group I to the Fifth Assessment Report of the Intergovernmental Panel on Climate Change, Cambridge University Press, Cambridge., Cambridge, United Kingdom and New York, NY, USA.

Strass, V. H., E. Fahrbach, U. Schauer, and L. Sellmann (1993), FORMATION OF DENMARK STRAIT OVERFLOW WATER BY MIXING IN THE EAST GREENLAND CURRENT, J. Geophys. Res.-Oceans, 98(C4), 6907-6919, doi:10.1029/92jc02732.

Swift, J. H., and K. Aagaard (1981), Seasonal transitions and water mass formation in the Iceland and Greenland seas, Deep Sea Res. Part Oceanogr. Res. Pap., 28(10), 11071129, doi:10.1016/0198-0149(81)90050-9. 
Swift, J. H., K. Aagaard, and S. A. Malmberg (1980), CONTRIBUTION OF THE DENMARK STRAIT OVERFLOW TO THE DEEP NORTH-ATLANTIC, Deep-Sea Res. Part-Oceanogr. Res. Pap., 27(1), 29-42, doi:10.1016/0198-0149(80)90070-9.

Tanhua, T., K. A. Olsson, and E. Jeansson (2005), Formation of Denmark Strait overflow water and its hydro-chemical composition, J. Mar. Syst., 57(3-4), 264-288, doi:10.1016/j.jmarsys.2005.05.003.

Thornalley, D. J. R., H. Elderfield, and I. N. McCave (2010), Intermediate and deep water paleoceanography of the northern North Atlantic over the past 21,000 years, Paleoceanography, 25(1), PA1211, doi:10.1029/2009PA001833.

Thornalley, D. J. R., M. Blaschek, F. J. Davies, S. Praetorius, D. W. Oppo, J. F. McManus, I. R. Hall, H. Kleiven, H. Renssen, and I. N. McCave (2013), Long-term variations in Iceland-Scotland overflow strength during the Holocene, Clim Past, 9(5), 2073-2084, doi:10.5194/cp-9-2073-2013.

Torrence, C., and G. P. Compo (1998), A Practical Guide to Wavelet Analysis, Bull. Am. Metereological Soc., 79, 61-78.

Vage, K., R. S. Pickart, M. A. Spall, H. Valdimarsson, S. Jonsson, D. J. Torres, S. Osterhus, and T. Eldevik (2011), Significant role of the North Icelandic Jet in the formation of Denmark Strait overflow water, Nat. Geosci, 4(10), 723-727.

Våge, K., R. S. Pickart, M. A. Spall, G. W. K. Moore, H. Valdimarsson, D. J. Torres, S. Y. Erofeeva, and J. E. Ø. Nilsen (2013), Revised circulation scheme north of the Denmark Strait, Deep Sea Res. Part Oceanogr. Res. Pap., 79(0), 20-39, doi:10.1016/j.dsr.2013.05.007.

Vellinga, M., and P. Wu (2004), Low-Latitude Freshwater Influence on Centennial Variability of the Atlantic Thermohaline Circulation, J. Clim., 17(23), 4498-4511, doi:10.1175/3219.1.

Werner, K., R. F. Spielhagen, D. Bauch, H. C. Hass, and E. Kandiano (2013), Atlantic Water advection versus sea-ice advances in the eastern Fram Strait during the last $9 \mathrm{ka}$ : Multiproxy evidence for a two-phase Holocene, Paleoceanography, 28(2), 283-295, doi:10.1002/palo.20028.

Whitehead, J. A. (1998), Topographic control of oceanic flows in deep passages and straits, Rev. Geophys., 36(3), 423-440, doi:10.1029/98rg01014.

Wilkenskjeld, S., and D. Quadfasel (2005), Response of the Greenland-Scotland overflow to changing deep water supply from the Arctic Mediterranean, Geophys. Res. Lett., 32(21), L21607, doi:10.1029/2005g1024140.

Zhang, R., T. L. Delworth, A. Rosati, W. G. Anderson, K. W. Dixon, H.-C. Lee, and F. Zeng (2011), Sensitivity of the North Atlantic Ocean Circulation to an abrupt change in the Nordic Sea overflow in a high resolution global coupled climate model, J. Geophys. Res., 116(C12), C12024, doi:10.1029/2011jc007240. 